\section{REFERENCES}

1. Arabi YM, Alhamid SM. Emergency room to the intensive care unit in Hajj. The chain of life. Saudi Med J. 2006;27(7):937-41.

2. Mansyur M. Indonesian Hajj health preparedness. Presented at: WHO Intercountry Consultation on Mass Gatherings Preparedness and Management; 2017 Feb 21-22; Jakarta.

3. Alzahrani AG, Choudhry AJ, Al Mazroa MA, Turkistani AH, Nouman GS, Memish ZA. Pattern of diseases among visitors to Mina health centers during the Hajj season, 1429 H (2008 G). J Infect Public Health. 2012;5(1):22-34.

4. Ministry of Health of the Republic of Indonesia. The Ministry Decree No 15 Year 2016 concerning Hajj health istithaah [Internet]. 2016 [cited 2020 May 28]. Jakarta: Ministry of Health of the Republic of Indonesia. Available from: http://hukor. kemkes.go.id/uploads/produk_hukum/PMK_No. 15_ttg_ Istithaah_Kesehatan_Jamaah_Haji_.pdf. Indonesian.
5. World Health Organization. Coronavirus disease (COVID-19) outbreak situation [Internet]. 2020 [cited 2020 May 28]. Available from: https://www.who.int/emergencies/diseases/ novel-coronavirus-2019?gclid=EAlalQobChMIveu8ouHC6QIVoZ 7CCh3bCQ1cEAAYASAAEgLB7PD BwE.

6. Indonesian Hajj Health Center, Ministry of Health of the Republic of Indonesia. 2016 Hajj health center performance report. Jakarta: Ministry of Health of the Republic of Indonesia; 2016. Indonesian.

7. Ahmed QA, Arabi YM, Memish ZA. Health risks at the Hajj. Lancet. 2006;367(9515):1008-15.

8. Ebrahim SH, Memish ZA. COVID-19: preparing for superspreader potential among Umrah pilgrims to Saudi Arabia. Lancet. 2020;395(10227):e48.

9. Yezli S, Mushi A, Yassin Y, Maashi F, Khan A. Knowledge, attitude and practice of pilgrims regarding heat-related illnesses during the 2017 Hajj mass gathering. Int J Environ Res Public Health. 2019;16(17):3215.

\title{
Hajj health management in Indonesia
}

Eka Jusup Singka, Innes Ericca

The Hajj, one of the five pillars of Islam, is a "once in a lifetime" mandatory worship for all Muslims. However, only those who meet certain conditions, collectively called "conditions of obligation," are obliged to perform the Hajj. These conditions are Islam religion, baligh or maturity, freedom, and istithaah or capability.
Check for updates

Istithaah is defined as the physical, mental, financial, and safe ability of a person to perform the pilgrimage without neglecting their familial responsibilities. Physical and mental istithaah, also known as health istithaah, is defined as the ability of pilgrims to perform Hajj rituals following Islamic guidance from the aspect of health.
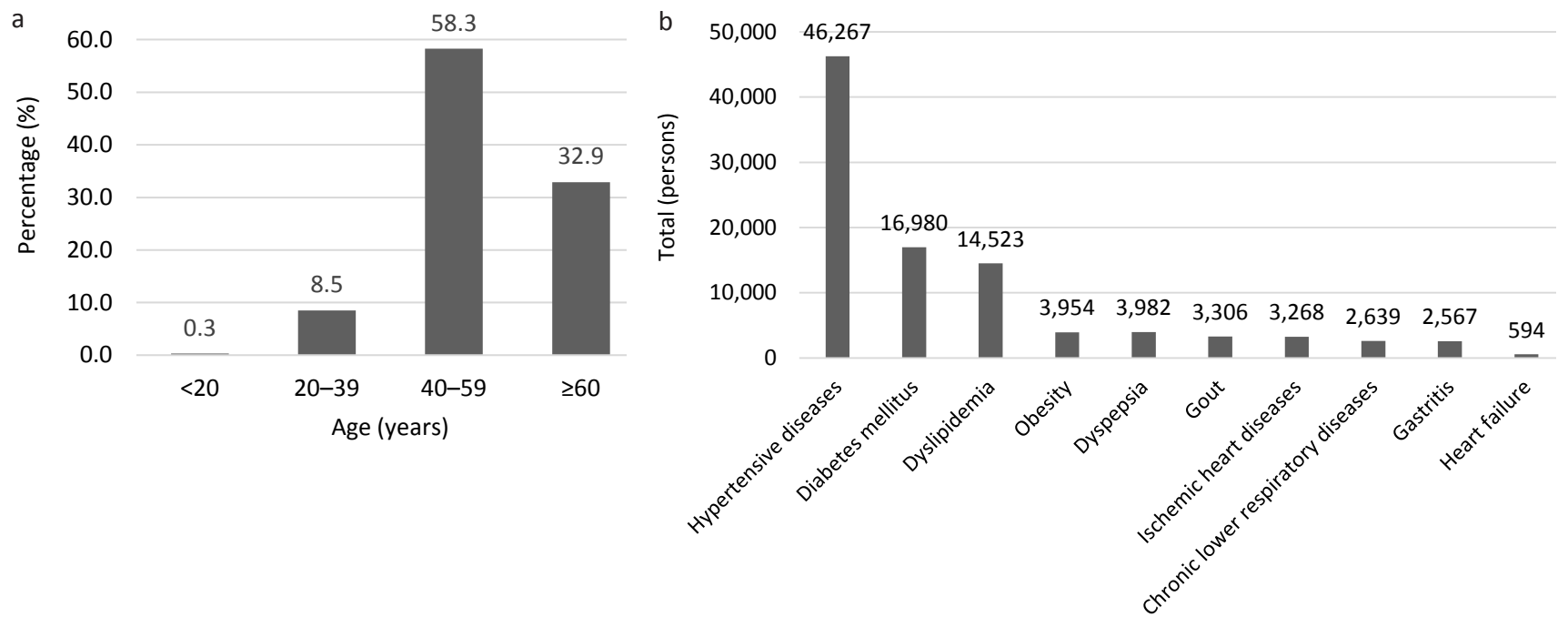

Figure 1. Estimated total number of Indonesian pilgrims for 2020. (a) Total number of Indonesian pilgrims according to age group; (b) ten most common preexisting diseases/condition of Hajj pilgrims

Copyright @ 2020 Authors. This is an open access article distributed under the terms of the Creative Commons Attribution-NonCommercial 4.0 International License (http:// creativecommons.org/licenses/by-nc/4.0/), which permits unrestricted non-commercial use, distribution, and reproduction in any medium, provided the original author and source are properly cited. For commercial use of this work, please see our terms at https://mji.ui.ac.id/journal/index.php/mji/copyright. 
Figure 2. Determinants of health in Indonesian pilgrims during Hajj

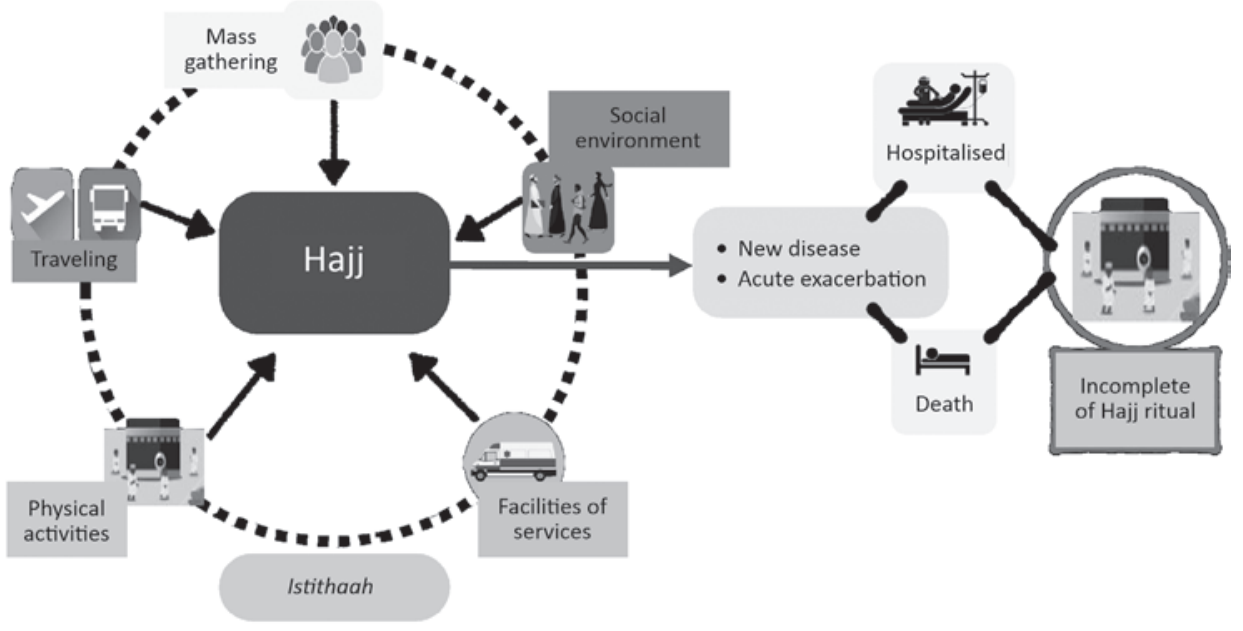

The Hajj takes place annually in Makkah, the holiest city for Muslims, from the $9^{\text {th }}$ to the $13^{\text {th }}$ of Dhu al-Hijjah. ${ }^{1}$ During the Hajj, millions of pilgrims gather in Makkah to perform a series of rituals, including Tawaf (circling Kaaba seven times), Sa'i (walking between Safa and Marwa seven times), Wukuf (standing at Arafat), Mabit (spending a night in Muzdalifah), and Jamarat (performing symbolic stoning of the devil by throwing stones at three pillars).

The Hajj is one of the greatest mass gatherings in the world. During the Hajj, approximately 3 million Muslims from over 180 countries gather in Makkah, Saudi Arabia, and the population density may reach as high as 7 persons $/ \mathrm{m}^{2}$; this means worshippers are exposed to significant health risks. ${ }^{2}$

Indonesia, the largest Muslim country in the world, contributes a sizable proportion of the number of Hajj pilgrims each year. Over 200,000 Indonesian Muslims travel to Saudi Arabia annually, and approximately 63$67 \%$ of these travelers are elderly and have metabolic or chronic diseases (Figure 1, a and b). Indeed, this group became more vulnerable to various diseases. Moreover, the long travel period from Indonesia to Saudi Arabia and differences in climate, food, and social and cultural conventions can contribute to the deterioration of the health condition of pilgrims and render them increasingly susceptible to health issues. Thus, the Hajj presents significant public health challenges for its organizers (Figure 2).

Considering the health challenges faced by its citizens during the Hajj, the Republic of Indonesia, through its Ministry of Health $(\mathrm{MoH})$, which is responsible for providing Indonesian health care, has implemented three key measures for Hajj health management, namely, health coaching/guidance, health service, and health protection (Figure 3). These three measures are applied in Indonesia, during the journey, and in Saudi Arabia to prepare and maintain the health conditions of Indonesian pilgrims. These measures aim to help pilgrims complete the Hajj rituals as required by Islam and return to Indonesia healthy. Every year, the $\mathrm{MoH}$ sends approximately 1,800 Indonesian health
Figure 3. Principles of Hajj health management in Indonesia
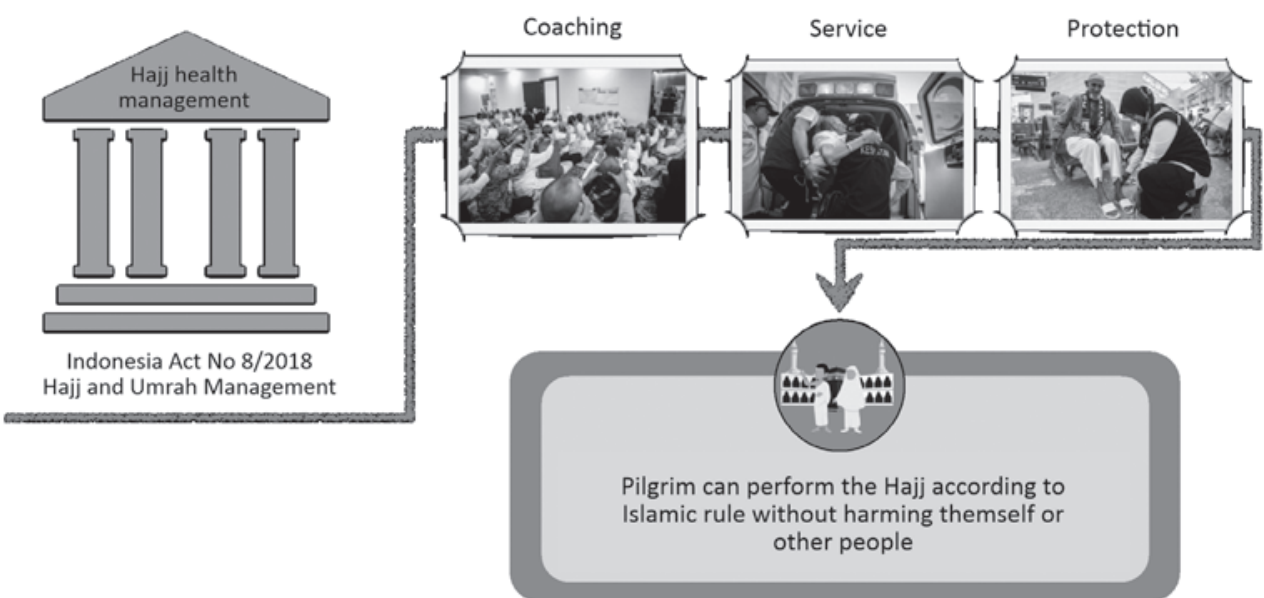

mji.ui.ac.id 
workers to execute its health guidance, service, and protection programs in Saudi Arabia.

In 2016, the $\mathrm{MoH}$ released Regulation No. 15, which describes the health istithaah of Indonesian pilgrims. This regulation discussed the health examination and coaching/guidance protocols established for the Hajj to prepare pilgrims not just physically but also physiologically for their upcoming journey. The Arabic word "istitha'ah" is preferred to the Bahasa translation for "capability" for a specific reason. Istithaah is an "Al-Quran nomenclature" and exerts a physiological effect on pilgrims highlighting the importance of health capability during the Hajj. During the Hajj in Saudi Arabia, the $\mathrm{MoH}$ assigns a promotive and preventive team to provide health promotion and prevention tips to Indonesian pilgrims.

Other measures implemented in Hajj health management include health service and health protection. Health clinics are prepared for each embarkation in Indonesia, and Indonesian clinics are established in Jeddah, Makkah, and Madinah to serve Indonesian pilgrims with health problems or requiring hospitalization. Moreover, at least one doctor and two nurses are assigned to each pilgrim flight group (kloter) to provide health care for pilgrims during their Hajj journey.

In terms of health protection, the $\mathrm{MoH}$ provides meningitis meningococcal vaccination and personal protective equipment for all pilgrims. In addition, a special task force is established in Saudi Arabia to provide first aid and rapid health care responses at any time necessary, especially during peak Hajj periods in Arafat, Muzdalifah, and Mina.

From Center of Hajj Health, Ministry of Health of the Republic of Indonesia, Jakarta, Indonesia

pISSN: 0853-1773 • elSSN: 2252-8083

https://doi.org/10.13181/mji.com.204749

Med J Indones. 2020;29:117-9

Corresponding author:

Eka Jusup Singka

E-mail: e.singka@yahoo.com

\section{REFERENCES}

1. Singka EJ. Mengawal istithaah kesehatan haji. [place unknown: publisher unknown]; 2019. Indonesian.

2. Aldossari M, Aljoudi A, Celentano D. Health issues in the Hajj pilgrimage: a literature review. East Mediterr Health J. 2019;25(10):744-53 